\title{
'SINTA SAH BU' as Program Innovation of DPMPTSP Labor of Pekalongan Regency
}

\author{
Dyah Hariani \\ \{dyahhariani@gmail.com\} \\ Universitas Diponegoro, Indonesia
}

\begin{abstract}
Licensing services, often have several problems in its implementation. The innovation of Sinta Sah $B u$ is the answer to the problem of licensing services in the Pekalongan. This research aims to analyze the innovation process of Sinta Sah Bu, as well as supporting factors and the termination. The results of this qualitative research showed that the process of innovation Sinta Sah Bu originated from the communication between the community and licensing services, then the implementation of innovation is done by the addition of service time on Friday night. Awareness and willingness to change, freedom of speech, and adequate infrastructure, are supporting factors of Sinta Sah Bu. The inhibitor factors are: There is no exceptional budget, and incentive for additional hours of service working time, although Sinta Sah Bu has been doing well enough to improve licensing services in the regency of Pekalongan.
\end{abstract}

Keywords: Innovation, Licensing, Human Resources, Budge, Incentive

\section{Introduction}

Public service is currently a necessity that cannot be separated from citizen's daily life in Indonesia. This situation led the local government to an effort for improving the image of public services in society by creating a service innovation. The service innovation could be an alteration that has new nature, implemented in a planned, conscious, and deliberate manner [1] or a new production process technology, new structural and administrative system, and new plans for organizational [2]. The Pekalongan Government in the affairs of public service innovation made a breakthrough to encourage the realization of good public services in its bureaucracy by increasing $150 \%$ of the additional employee income (TPP), with the assumption that ASN might be better in its public service. In the 2016 until 2020, known that from 72 OPD (Regional Device Organizations) in Pekalongan Regency, only 16 OPD (Regional Apparatus Organization) did a public service innovation. It shows that the terms of the seriousness in making public service innovation less done by ODP in Pekalongan regency. Moreover, ODP only focuses on carrying out daily tasks without trying to improve their performance through public service innovation even though some others are accomplished pioneers in initiating public service innovation [3].

The Investment and One-Stop Integrated Service and Labor (DPMPTSP Labor) Office of Pekalongan regency is one of the OPD that implementing the public service innovation. The innovation called Sinta Sah Bu (A steady solution for busy entrepreneurs) which supports the implementation of licensing service for busy entrepreneurs. This innovation is known to be intended for entrepreneurs who do not have a license in their business and some other 
licensing documents. The reason behind this innovation was the services carried out by The Investment and One-Stop Integrated Service and Labor (DPMPTSP Labor) Office of Pekalongan regency previously only preoccupied with working hours only. Consequently, the entrepreneurs who were busy during working time could not properly manage their license business, from these problems The Investment and One-Stop Integrated Service and Labor (DPMPTSP Labor) office finally made Sinta Sah Bu innovation (A steady solution for busy entrepreneurs) in the office of investment and integrated service of one door and labor (DPMPTSP Labor) Pekalongan regency with the expectation of the public service can be better than previously.

However, the process of implementing Sinta Sah Bu's innovation must go through several stages such as initial stage and implementation stage. On the other hand, there are various factors that can affect it such as [4]:

a. There is a desire to changes from not able to be able or not knowing become knowing

b. There is freedom of expression

c. The existence of mentors who are broad-minded and creative

d. The availability of facilities and infrastructure

e. Harmonious environmental conditions such as harmonious family environment, association, and school.

In order to find out how this innovation being implemented, the author is interested to do research about how the implementation of Sinta Sah Bu innovation and the affected factors in the DPMPTSP Labor Pekalongan Regency.

\section{Method}

This study uses descriptive qualitative methods. The data in the study was obtained through interviews which then became primary data and documentation as secondary data [5]. Qualitative research is research that generates descriptive data from the people and behavior that can be observed. This method will be suitable to be used in this research [6]. Moreover, the qualitative research likely departed from a specific case in a social situation therefore qualitative research does not use the population [7], but uses the informant or participants in the subject of research. The informant in this research was chosen by their knowledge about the topic or known as purposive sampling. Furthermore, the informant chosen consist of Head of licensing department and the 2 staff. The data analysis used in this research is a domain analysis technique, where the analysis is carried out after going through the process from direct observation into the research object in the form of social situations (place, actors, activities) [8].

\section{Result and Discussion}

Sinta Sah $B u$ is an innovation in the form of an online system to take care of business licensing. The implementing process of Sinta Sah Bu can be observed through several things. According to Zalman et al. [9] this process can be divided into two stages, namely the initial stage and the subsequent implementation has several steps in it.

The result of this research showed that implementation of Sinta Sah Bu innovation based on the innovation process: 


\subsection{Initial Stage}

\subsubsection{Knowledge and Awareness Step}

This step is related to the awareness of potential recipients of innovation who truly need innovation [9]. The result showed that the business license management services and other licensing such as IMB (building permits), etc. Licensing is very important for the entrepreneurs, because they need the licensing for running their business. Meanwhile for the government the licensing is very important to monitor the development of the business in its territory. In the old management, it took a long time for the entrepreneurs for minding a business licensing and most of the entrepreneurs didn't have much time to mind it. The Investment and One-Stop Integrated Service and Labor (DPMPTSP Labor) office, Pekalongan regency realized about the problem and it needs to be resolved. The DPMPTSP Labor Pekalongan regency responds to the reports and complains from the community which is submitted directly and some through the apparatus of DPMPTSP Labor Pekalongan Regency. The Investment and One-Stop Integrated Service and Labor (DPMPTSP Labor) office, Pekalongan regency who realized that the organization has several problems, in this case, find out about how the licensing management services become easier and more affordable for all circles. Then, they created an innovation namely 'Sinta Sah Bu'. The creation of Sinta Sah Bu innovation can be seen as a tool and hope that the One Door Integrated Investment and Service Office (DPMPTSP \& Naker) Pekalongan regency can run more advanced and licensing services satisfy the community as a whole.

\subsubsection{The Step Towards the Establishment of Attitudes Towards Innovation}

This step shows the conditions the organizational member in responding to innovation [9]. The research found that the creation of Sinta Sah $B u$ innovation service previously referred to the implementation of innovation based on the Sip Tenan application. Sip Tenan is an integrated licensing information system where the system utilizes an online system to collect all licensing information in an integrated manner. However, because of the community and the application which often faces several problems, consequently, the innovation isn't being continued. The termination was then replaced with a simpler and closer society with a more friendly service namely Sinta Sah Bu. Sinta Sah Bu innovation service is known to have three types of services from the addition of services on Friday nights, then services through messaging and WhatsApp video call, as well as on call services. In addition to the change of service to this online under Regulation No. 24 of 2018 [10] on Electronically Integrated Business Licensing Services.

\subsubsection{Decision Making Step}

The DPMPTSP Labor Pekalongan regency apparatus responded positively to this new step of innovation, in the pioneering process the apparatus planned for the implementation of innovation can run smoothly. In this step, all information about the potential evaluation for innovation is evaluated [6]. Through the process of dialogue and meetings finally began several agendas or steps in innovation from socialization to technical implementation, although it is known in terms of budget is required not to overload the budget of the Office, the apparatus continues to carry out the innovation of the service to the maximum. The decision to implement Sinta Sah Bu innovation is known to be a good step because in this case, it can make the bureaucratic chain shorter, then from the community be more flexible 
can access anywhere with complete requirements file defects, then for file retrieval can be sent through the file or can communication to determine when permission is taken.

\subsection{The Implementation Steps}

\subsubsection{The First Step (The Beginning of Innovation)}

Sinta Sah Bu started in October 2019, the innovation started from the socialization step to the community both in the sub-districts in Pekalongan Regency and through the installation of billboards, and also the distribution of brochures to the use of social media. This step is the organization's attempt to implement some innovation [6]. The start of the innovation implementation began with the opening of additional time services on Friday night and through WhatsApp contacts, entrepreneurs who previously had no time to mind about the licensing took some time to respond by participating in the innovation service then. The people who mind the permits are mostly micro-medium entrepreneurs.

The community as the object of the innovation respond positively about the innovation and they also participate in it. It caused by the changes of the services that are easier enough to reach. The citizen needs Smartphones only to reach the services, in other ways the community is guided directly if they have difficulty through WhatsApp video call service and one call service or they can visit DPMPTSP Labor office directly. The service makes the permit administrators able to adjust the service more easily, although in this case, it is necessary commitment and sincerity in the service so that the satisfaction of the community is guaranteed well. Over time, the community is increasingly aware and active in permit management, socialization continues to be done from before directly then switch to be more active on social media. The creation of content both posters and videos in this case is done to make Sinta Sah Bu's innovations more developed and reach out to more busy permit administrators during working hours.

\subsubsection{Continuous Step to Fostering Innovation Implementation}

The implementation of the Sinta Sah Bu innovation service for some time has been known as an innovation that facilitates and needed by the community. In this era that requires practicality plus flexibility of service is an important thing to make the service more primed. The continuous step to fostering innovation implementation relates to innovation implementation coaching activities [9]. Sinta Sah Bu's innovation, in this case, is under Permenpan RB Number 23 of 2017 [11] about the implementation of a public service mall that makes public services closer to the community. Sinta Sah $B u$ evaluation is known to be done once a week either during service on Friday night (after Sinta Sah Bu) or when the service is deserted, the evaluation discussion starts from the initial flow of service, then the speed of licensing services and the community's convenience.

The result of the research shows that in this step the human resources development in Sinta Sah Bu service is known to be none, nevertheless training or regular coaching that once a year in BKD remains there to support the capacity increase of the apparatus of DPMPTSP Labor Pekalongan Regency. Another coaching that exists more to the internal Office itself than the head of the office, the head of the department, and some of its ranks, nevertheless in terms of competence and knowledge of the officer of the licensing officer DPMPTSP Labor Pekalongan Regency is good enough. The development of the implementation of Sinta Sah Bu was known during the service on Friday night, DPMPTSP Labor Pekalongan District provides free coffee for permit applicants. The provision of coffee is a step result of evaluation where 
while waiting for the queue the community can be more comfortable, it is important to make the community more orderly and avoid the use of the 3rd party (touts). The discussion of Sinta $\mathrm{Sah} B u$ in the future is expected to change the call center number to be more concise and memorable, this according to DPMPTSP Labor Pekalongan Regency is a step to make the community more remembered for an easy service named Sinta Sah Bu.

Moreover, the results of the analysis of the implementation of Sinta Sah Bu innovation in DPMPTSP Labor in Pekalongan Regency also shows several factors that affected the implementation as expressed by Rogers [4] those are:

\subsection{Supporting Factors}

1) DPMPTSP Labor Pekalongan Regency at the beginning knew of a problem in licensing service, afterward the problem was taken seriously through meetings and communicated between leaders with the result that in development will appear Sinta Sah Bu innovation. Base on the fact, this change to change from the previous DPMPTSP Labor in Pekalongan Regency has not been able to serve properly, and now it is changing with additional time on Friday nights through the WhatsApp application. It shows that there is a desire to changes them self from not able being able or not knowing become knowing.

2) High freedom of opinion between the apparatus, in this case, encourages the birth of innovation, from the previous communication that has not been effective in resolving problems but the input from the community and the existence of better service goals from head office made Sinta Sah Bu innovation services can be applied, after that in the internal evaluation as well as giving coffee is a step that makes the community more positively receiving the presence of Sinta Sah Bu on Friday night services.

3) The DPMPTSP Labor in Pekalongan Regency in the implementation of Sinta Sah Bu, they have a mentor who expert about the flow of licensing according to Government Regulation Number 24 the year 2018 [10] about Electronically Integrated Business Licensing Services or the Online Single Submitting (OSS) system and understand Microsoft Office.

4) The availability of facilities and infrastructure: The facilities and infrastructure to have supported the implementation of Sinta Sah Bu innovation. The existing facilities from the service area are comfortable and supporting tools such as computers, etc. are still functioning properly.

5) The environmental conditions in the office to the staff of DPMPTSP Labor in Pekalongan regency has a family atmosphere. This condition is done to create the working relationship between the apparatus better and to give each other constructive suggestions if there are problems.

\subsection{Inhibiting Factor}

1) Short-term budget: In the matter of budget, that Sinta Sah Bu has not yet budgeted. According to the innovation, the program is still being piloted. The existing service works as usual and uses a short-term budget.

2) Sinta $\mathrm{Sah} B u$ is holding on to the network created by the central government refer to OSS, the DPMPTSP in Pekalongan regency apparatus become dependent if there is damage to the system with the result that the implementation of licensing is delayed for a long time, therefore, waiting for the improvement role of the central government. 
3) Lack of rewards or incentives: Incentives provided by the local government do not exist. In this case, will create weaken the service commitment of the apparatus indirectly with the result that Sinta Sah Bu does not work proficiently.

\section{Conclusions}

Finally, we can conclude that Sinta Sah Bu innovation is an innovation that is carried out to create the licensing process in Pekalongan regency being easier especially for busy entrepreneurs. Sinta Sah $B u$ changes the licensing system from a traditional process in which the entrepreneurs have to mind the licensing directly to the DPMPTSP Labor into simpler ways by through WhatsApp messages and video calls, call service or from the DPMPTSP Labor Pekalongan Regency to visit the license participant. Moreover, there is also additional time on Friday night for entrepreneurs who are busy during working time. In the end, judging by the innovation process, it can be said that Sinta Sah Bu as an innovation from DPMPTSP Naker is good enough.

The result also shows that the supporting factors for Sinta Sah Bu innovation consist of the desire to change oneself from the DPMPTSP Labor Pekalongan regency, after that the freedom of expression, the role of a broad-minded and creative mentor, and the availability of facilities and infrastructure, afterward in a harmonious environment to be developed innovation.

Meanwhile the inhibiting factors for Sinta Sah Bu innovation consist of there is no special budget provided for development service, administrative problems where it still depends on the central government about the licensing system, moreover there is no incentive for the overtime apparatus.

Suggestions that can be given from the results of the analysis are:

a. It is needed to improve the apparatus skill and also their commitment through training is needed to create the quality of the Sinta Sah Bu service even better.

b. Procuring special budgeting for Sinta Sah Bu to create the development of services from facilities and infrastructure for the community can be more comfortable when applying for a license.

c. Providing incentives to Sinta Sah Bu servants is needed to create commitment and the spirit of service is proficiently maintained.

\section{Reference}

[1] T. Halvorsen, J. Hauknes, I. Miles, and R. Røste, "On the differences between public and private sector innovation," Publin Rep. D, vol. 9, p. 64, 2005.

[2] Y. Suwarno, “Inovasi Di Sektor Publik," J. Adm. Publik, vol. 5, no. 2, 2008.

[3] Aris, "Bupati Pekalongan Tegaskan Tahun 2020 Seluruh OPD Wajib Berinovasi," 2020. [Online]. Available: https://pekalongankab.go.id/index.php/ar/blog2/108-berita/beritalokal/11435-bupati-pekalongan-tegaskan-tahun-2020-seluruh-opd-wajib-berinovasi. [Accessed: 16-Feb-2020].

[4] N. U. Divani and D. Hariani, "Inovasi Pusat Pengelolaan Pengaduan Masyarakat (P3M) di Pusat Informasi Publik (PIP) Balai Kota SemaraNG," J. Public Policy Manag. Rev., vol. 7, no. 2, pp. 233-251, 2018.

[5] Sugiyono, Metode Penelitian Kuantitatif, Kualitatif dan $R \& D$ Metode. Bandung: Alfabeta, 2017.

[6] S. Siyoto and M. A. Sodik, Dasar metodologi penelitian. Literasi Media Publishing, 2015. 
[7] Sugiyono, Metode Penelitian Pendidikan Pendekatan Kuantitatif, Kualitatif, dan $R \& D$. Bandung: Alfabeta, 2009.

[8] Sugiyono, "Metode Penelitian Kuantitatif, Kualitatif dan R\&D," Alf. Bandung, 2014.

[9] U. S. Sa'ud, Inovasi Pendidikan. Bandung: Alfabeta, 2010.

[10] "Peraturan Pemeritah Nomor 24 Tahun 2018 Tentang Pelayanan Perizinan Berusaha Terintegrasi Secara Elektronik."

[11] "Permenpan RB Nomor 23 Tahun 2017 Tentang Penyelenggaraan Mall Pelayanan Publik." 